\title{
EFFICIENCY OF PHOSPHORUS USE IN YOUNG PLANTS OF Eucalyptus urophylla S. T. Blake
}

\author{
Thais Galhardo Godoy ${ }^{1}$, Sebastião Carlos da Silva Rosado²
}

(received: March 10, 2010; accepted: April 28, 2011)

\begin{abstract}
The objective of this study is to select superior genotypes for efficiency of phosphorus use in seedlings of Eucalyptus urophylla, correlating them with initial height growth in the field, at age eight months. A completely randomized block design was used in the nursery, consisting of eight clones, three replicates and four plants per plot. The same design was used in the field, consisting of eight clones, four replicate blocks and nine plants per plot. Data being collected in the nursery at age 120 days included: phosphorus concentration in shoot (CPPA); phosphorus concentration in root (CPR); phosphorus content in shoot (CtPPA); phosphorus content in root (CtPR); total phosphorus content in seedling (CtPT); phosphorus use efficiency in shoot (EUP-PA); phosphorus use efficiency in root (EUP-R) and total phosphorus use efficiency (EUP-T). Analyses of variance showed significant genetic differences among clones for all traits and, given the high heritability values found, estimated genetic gains were generically very high. As regards predicted indirect genetic gain, it was noted that selection on nursery seedlings for all EUPs provided the highest values of indirect gain in height of field seedlings.
\end{abstract}

Key words: Initial growth of seedlings, phosphorus use efficiency, genetics.

\section{EFICIÊNCIA DE UTILIZAÇÃO DE FÓSFORO EM PLANTAS JOVENS DE Eucalyptus urophylla S. T. Blake}

RESUMO: Objetivou-se, com este trabalho, a seleção de genótipos superiores para a eficiência de utilização de fósforo em mudas de Eucalyptus urophylla, correlacionando-as com o crescimento inicial em altura no campo, aos oito meses de idade. $O$ delineamento usado no viveiro foi o de blocos inteiramente casualizados, com oito clones, três repetições e quatro plantas por parcela. O delineamento utilizado no campo também foi de blocos inteiramente casualizados, com oito clones, quatro blocos e nove plantas por parcela. Os dados coletados no viveiro aos 120 dias de idade foram: concentração de fósforo na parte aérea (CPPA); concentração de fósforo na raiz (CPR); conteúdo de fósforo na parte aérea (CtPPA); conteúdo de fósforo na raiz (CtPR); conteúdo de fósforo total na muda (CtPT); eficiência de utilização do fósforo na parte aérea (EUP-PA); eficiência de utilização de fósforo na raiz (EUP-R) e eficiência de utilização do fósforo total (EUP-T). As análises de variância mostraram que existem diferenças genéticas significativas entre clones para todas as características e, tendo em vista os altos valores de herdabilidade encontrados, os ganhos genéticos estimados foram de grande magnitude. No estudo de previsão de ganho genético indireto, verificou-se que a seleção, em mudas no viveiro, para todas as EUP propiciou os maiores valores de ganho indireto em altura das mudas no campo.

Palavras-chave: Crescimento inicial de mudas, eficiência de uso de fósforo, genética.

\section{INTRODUCTION}

Species of genus Eucalyptus play an important part in the Brazilian social, economic and environmental scene. Up until 2007, an estimated 3,771,867 ha in area was reforested with Eucalyptus (ASSOCIAÇÃO BRASILEIRA DE PRODUTORES DE FLORESTAS PLANTADAS - ABRAF, 2008), expected to produce enough timber to cater for the Brazilian industrial sector, in particularly cellulose pulp production and charcoalfuelled steel metallurgy.

From a nutritional standpoint, a superior species and/or genotype is one that is capable of developing and producing good yields under unfavorable fertility conditions, and having the ability to absorb the required nutrients in smaller quantities and/or distribute them more efficiently to various plant components, without affecting productivity (FURLANI et al., 1984).

Species with an enhanced ability to absorb and/or use nutrients would be more desirable. This is so because not only would they make better use of the nutrients being supplied via fertilization, but smaller amounts of nutrients should suffice (LUCA, 1997), resulting in greater biomass yield, which is an important characteristic for successful growth and improved productivity where soils are low in P levels (MACHADO, 2000).

Bearing that in mind, the objective of this work is to select superior genotypes for phosphorus uptake efficiency in clonal seedlings of Eucalyptus urophylla, estimating variance components for phenotypic, genotypic and

${ }^{1}$ Forest Engineer - Departamento de Ciências Florestais - Universidade Federal de Lavras/UFLA - Cx. P. 3037 - 37200-000 - Lavras, MG, Brasil thais_galhardo@yahoo.com.br

${ }^{2}$ Forest Engineer, Professor PhD in Forest Improvement - Departamento de Ciências Florestais - Universidade Federal de Lavras/UFLA - Cx. P. 3037 37200-000 - Lavras, MG, Brasil - scrosado@dcf.ufla.br

Cerne, Lavras, v. 17, n. 3, p. 303-308, jul./set. 2011 
environmental parameters, as well as heritability, direct and indirect genetic gains, correlating them to young plants in the field at age eight months.

\section{MATERIAL AND METHODS}

Clonal seedlings were used in this experiment, as produced by the minicutting technique (vegetative propagation) in the forest nursery of Carvovale Ltda. The nursery is located in the municipality of Taiobeiras, in Vale do Jequitinhonha region, at coordinates $42^{\circ} 14^{\prime} 10^{\prime \prime}$ west longitude and $15^{\circ} 48^{\prime} 30^{\prime \prime}$ south latitude. According to Köppen classification, the predominant local climate is dry, continental, with average annual precipitation less than $1,000 \mathrm{~mm}$ and average maximum temperature around $34^{\circ} \mathrm{C}$ (COMPANHIA DE PESQUISA DE RECURSOS MINERAIS - CPRM, 2004).

Seedlings were produced in tubes with a volume capacity of $50 \mathrm{~cm}^{3}$ and stored in plastic trays containing 96 cells, suspended $80 \mathrm{~cm}$ above ground level. The substrate used consisted of $40 \%$ vermiculite, $30 \%$ scorched rice husk, $10 \%$ coconut fiber, $20 \%$ slash pine bark and needles, at a $\mathrm{pH}$ of 5.5.

In the nursery, eight clones were assessed using a completely randomized block design, with three replicates and four plants per plot. In the field, the same design was used consisting of eight clones with four replicates and nine plants per plot, at age eight months, arranged at $3 \times 2 \mathrm{~m}$ spacing. According to Tomé (2002), in order to obtain more precise estimates of treatment means or selection gain, models with a random progeny effect are more suitable. This is so because the effects of progenies are better represented by random effects, since the usual assumption in quantitative genetics is that genetic values related to a genotype result from the sum of small effects of individual contributions from a large number of Mendelian segregating genes for trait manifestation.

At age 120 days, the root portion of each seedling was washed carefully, trying to preserve roots as much as possible. The vegetal materials were placed in labeled paper bags and taken to a forced air oven at $70^{\circ} \mathrm{C}$, to a constant weight. They were then ground using a stainless steel Wiley mill and submitted to the Laboratory of Leaf Analysis of the Departamento de Ciência do Solo of the Universidade Federal de Lavras (UFLA) where, using a nitric-perchloric mixture, $\mathrm{P}$ concentrations were determined in the shoot and root portions, by colorimetry (ASSOCIATION OF OFFICIAL ANALYTICAL CHEMISTS - AOAC, 1975).

Cerne, Lavras, v. 17, n. 3, p. 303-308, jul./set. 2011
The following data were collected: height of field seedlings after eight months $(\mathrm{Hc})$; phosphorus concentration in shoot (CPPA); phosphorus concentration in root (CPR); $\mathrm{P}$ content in shoot (CtPPA); P content in root (CtPR); total $\mathrm{P}$ content in seedling (CtPT); phosphorus use efficiency in shoot (EUP-PA); phosphorus use efficiency in root (EUP-R); total phosphorus use efficiency (EUP-T). Efficiencies were calculated on the basis of the following methodologies: Siddiqui and Glass (1981) and Swiader et al. (1994).

Data were submitted to analysis of variance, following program procedures in GENES (CRUZ, 2001). The statistical model used was:

$$
\mathrm{Y}_{\mathrm{ij}}=\mu+\mathrm{g}_{i}+b_{j}+\varepsilon_{j i}
$$

where: $Y_{\mathrm{ij}}$ is the mean value observed in the $\mathrm{i}^{\text {th }}$ genotype of the $j^{\text {th }}$ block; $\mu$ is grand mean; $g_{i}$ is effect of the $i^{\text {th }}$ genotype (random effect); $b_{j}$ is effect of the $j^{\text {th }}$ block (random effect); $\varepsilon_{\mathrm{ji}}$ is experimental error.

The analysis of variance summary and expected mean square values for estimates of phenotypic, genotypic and environmental parameters are provided in Table 1.

Table 1 - Analysis of variance summary and expected mean square values for phenotypic, genotypic and environmental parameters.

Tabela 1 - Esquema da análise de variância e estimativa das esperanças dos quadrados médios para os parâmetros fenotípicos, genotípicos e ambientais.

\begin{tabular}{lccc}
\hline Source & MS & E(MS) & F \\
\hline Block (B) & MSB & $\hat{\sigma}^{2}+g \hat{\sigma}_{b}^{2}$ & - \\
Clone (G) & MSG & $\hat{\sigma}^{2}+b \hat{\sigma}_{g}^{2}$ & MSG/MSR \\
Residual (R) & MSR & $\hat{\sigma}^{2}$ & - \\
\hline$\hat{\sigma}^{2}:$ residual variance; $\hat{\sigma}_{g}^{2}$ : genotypic variance; $\hat{\sigma}_{b}^{2}$ : variance
\end{tabular}
between blocks; g: number of genotypes; b: number of blocks.

Estimates of variance components, values of heritability and coefficients of variation were derived according to expressions described by Cruz and Carneiro (2003).

Gains were predicted by selecting one in four clones being assessed ( $25 \%$ selection), normalizing selection intensity at 1.400 (COTTERIL; DEAN, 1990).

\section{RESULTS AND DISCUSSION}

From Table 2 data, significant differences are noted among clones, by the $F$ test $(p \leq 0.01)$, for initial height 
Table 2 - Analysis of variance summary and estimate of genetic, phenotypic and environmental parameters for nutritional characteristics and height of young field plants, at age eight months, of E. urophylla clones.

Tabela 2 - Resumo da análise de variância e estimativa dos parâmetros genéticos, fenotípicos e ambientais para características nutricionais e altura de plantas jovens no campo, aos oito meses de idade, de clones de E. urophylla.

\begin{tabular}{|c|c|c|c|c|c|c|c|c|c|c|}
\hline \multirow[b]{2}{*}{ Source } & \multirow[b]{2}{*}{ GL } & \multicolumn{9}{|c|}{ Mean Square } \\
\hline & & $\begin{array}{l}\mathrm{Hc} \\
(\mathrm{m})\end{array}$ & $\begin{array}{c}\text { CPPA } \\
\left({\left.\mathrm{g} . \mathrm{kg}^{-1}\right)}\right.\end{array}$ & $\begin{array}{c}\text { CPR } \\
\left({\left.\mathrm{g} . \mathrm{kg}^{-1}\right)}\right.\end{array}$ & $\begin{array}{c}\text { CtPPA } \\
\left.\text { (mg.plant }^{-1}\right)\end{array}$ & $\begin{array}{c}\text { CtPR } \\
\left(\text { mg.plant }{ }^{-1}\right)\end{array}$ & $\begin{array}{c}\text { CtPT } \\
\left(\text { mg.plant }{ }^{-1}\right)\end{array}$ & $\begin{array}{l}\text { EUP-PA } \\
\left(\mathrm{g}^{2} \cdot \mathrm{mg}^{-1}\right) \\
\end{array}$ & $\begin{array}{c}\text { EUP-R } \\
\left(\mathrm{g}^{2} \cdot \mathrm{mg}^{-1}\right)\end{array}$ & $\begin{array}{c}\text { EUP-T } \\
\left(\mathrm{g}^{2} \cdot \mathrm{mg}^{-1}\right)\end{array}$ \\
\hline Block & 2 & 0.0262 & 7.0 & 4.4 & 0.000012 & 0.0012 & 0.00013 & 2.3 & 1.8 & 1.8 \\
\hline Clone & 7 & $0.272 * *$ & $312.4 * *$ & $223.3 * *$ & $0.000832 * *$ & $0.0181 * *$ & $0.00656 * *$ & $141.9 * *$ & $13.9086 * *$ & $45.9 * *$ \\
\hline Residual & 14 & 0.0543 & 6.9 & 28.5 & 0.000007 & 0.0011 & 0.00021 & 5.4 & 1.7905 & 2.8 \\
\hline Mean & & 2.45 & 44.00 & 52.20 & 0.04 & 0.21 & 0.12 & 20.70 & 7.80 & 13.60 \\
\hline $\mathrm{CV}_{\mathrm{e}}(\%)$ & & 9.5 & 6.0 & 10.2 & 6.9 & 15.6 & 11.7 & 11.2 & 16.9 & 12.2 \\
\hline $\mathrm{CV}_{\mathrm{g}}(\%)$ & & 11.0 & 22.9 & 15.4 & 42.6 & 35.4 & 37.4 & 32.6 & 25.5 & 27.9 \\
\hline$\sigma_{f}^{2}$ & & 0.09079 & 104.145 & 74.45 & 0.000272 & 0.006 & 0.00219 & 47.303 & 4.6362 & 15.296 \\
\hline$\sigma_{\mathrm{e}}^{2}$ & & 0.01811 & 2.313 & 9.512 & 0.000002 & 0.00037 & 0.00007 & 1.782 & 0.5968 & 0.925 \\
\hline $\mathrm{D}$ & & 0.07268 & 101.831 & 64.939 & 0.00027 & 0.0057 & 0.00212 & 45.52 & 4.0394 & 14.371 \\
\hline $\mathrm{h}^{2}(\%)$ & & 80.0 & 97.8 & 87.2 & 99.1 & 83.7 & 96.8 & 96.2 & 87.1 & 94.0 \\
\hline $\mathrm{CV}_{\mathrm{g}} / \mathrm{CV}_{\mathrm{e}}$ & & 1.16 & 3.83 & 1.51 & 6.15 & 2.27 & 3.20 & 2.92 & 1.50 & 2.28 \\
\hline
\end{tabular}

** P $\leq 0.01$; Hc: height of field seedlings, after eight months; CPPA: P concentration in shoot; CPR: P concentration in root; CtPPA: P content in shoot; CtPR: P content in root; CtPT: total P content; EUP-PA: P use efficiency in shoot; EUP-R: P use efficiency in root; EUP-T: total $\mathrm{P}$ use efficiency; $\mathrm{CV}_{\mathrm{e}}$ : experimental coefficient of variation (error); $\mathrm{CV}_{\mathrm{g}}$ : genetic coefficient of variation; $\sigma_{\mathrm{f}}^{2}$ : phenotypic variation; $\sigma_{\mathrm{e}}^{2}$ : environmental variation, $\sigma_{\mathrm{g}}^{2}$ : genetic variation; $\mathrm{h}^{2}$ : coefficient of genotypic determination; $\mathrm{CV}_{\mathrm{g}} / \mathrm{CV}_{\mathrm{e}}: \mathrm{variation}$ index.

growth in the field, $\mathrm{P}$ concentration, $\mathrm{P}$ content and $\mathrm{P}$ use efficiency. This indicates the possibility of selecting clones with higher field yielding potential, particularly under conditions of P deficiency.

These traits had mean values of $2.45 \mathrm{~m}(\mathrm{Hc}) ; 44.0 \mathrm{~g}$. $\mathrm{kg}^{-1}$ (CPPA); 52.2g.kg ${ }^{-1}$ (CPR); 0.04mg.plant ${ }^{-1}$ (CtPPA); $0.21 \mathrm{mg}^{\text {plant }}{ }^{-1}$ (CtPR); 0.12mg.plant ${ }^{-1}$ (CtPT); 20.7 $\mathrm{g}^{2}$. $\mathrm{mg}^{-1}$ (EUP-PA); $7.8 \mathrm{~g}^{2} \cdot \mathrm{mg}^{-1}$ (EUP-R) and $13.6 \mathrm{~g}^{2} \cdot \mathrm{mg}^{-1}$ (EUP-T). The experimental coefficients of variation $\left(\mathrm{CV}_{\mathrm{e}}\right)$ ranged from $6.0 \%$ (CPPA) to $16.98 \%$ (EUP-R). According to Gomes et al. (2002), low $\mathrm{CV}_{\mathrm{e}}$ values indicate good experimental precision, particularly in terms of environmental control and data collection.

In these nutritional traits, $\mathrm{CV}_{\mathrm{g}}$ values ranged from $15.4 \%$ (CPR) to $42.6 \%$ (CtPPA). Now, considering these genotypic and environmental coefficients of variation, the following $\mathrm{CV}_{\mathrm{g}} / \mathrm{CV}_{\mathrm{e}}$ ratios are provided: $1.16(\mathrm{Hc}), 3.83$ (CPPA), 1.51 (CPR), 6.15 (CtPPA), 2.27 (CtPR), 3.20 (CtPT), 2.92 (EUP-PA), 1.50 (EUP-R) and 2.28 (EUP-T). According to Vencovsky and Barriga (1992), successful selection is guaranteed if the above ratio is 1.0 or more. Therefore, the obtained results indicate the possibility of success for all growth traits being assessed, particularly $\mathrm{P}$ content in the shoot portion (CtPPA).

According to the above table, heritability $\left(\mathrm{h}^{2}\right)$ had percentage values of 80.0 (Hc), 97.8 (CPPA), 87.2 (CPR), 99.1 (CtPPA), 83.7 (CtPR), 96.8 (CtPT), 96.2 (EUP-PA), 87.1 (EUP-R) and 94.0 (EUP-T). From these high $\mathrm{h}^{2}$ coefficients and the high $\mathrm{CV}_{\mathrm{g}} / \mathrm{CV}_{\mathrm{e}}$ ratios, relatively high gains can be predicted for the traits being assessed.

Table 3 provides predicted genetic gains to be attained from direct selection for initial height growth in the field, as assessed eight months after planting ( $\mathrm{Hc})$, and for P nutritional traits, as well as indirect gains in Hc with selection for nutritional traits CPPA, CPR, CtPPA, CtPR, CtPT, EUP-PA, EUP-R and EUP-T.

In forest improvement programs, correlations are used to assist with selection involving two traits simultaneously, in other words, selection on one trait may have reflections, positive or negative, on another. Where reflections are positive, gains are directly obtained in the selected trait and indirect gains are obtained in the correlated trait. However, for this to happen, it is necessary that the genotypic correlation among the traits of interest be relatively high.

Cerne, Lavras, v. 17, n. 3, p. 303-308, jul./set. 2011 
Table 3 - Direct gain (GD), genetic correlation $\left(\mathrm{r}_{\mathrm{g}}\right.$ ), indirect gain (GI) and indirect selection efficiency (ESI) for seedling nutritional parameters and height of young field plants, at age eight months, of E. urophylla clones.

Tabela 3 - Ganho direto (GD), correlação genética ( $\left.r_{g}\right)$, ganho indireto (GI) e eficiência de seleção indireta (ESI) para parâmetros nutricionais de mudas e altura de plantas jovens no campo, aos oito meses de idade, de clones de E. urophylla.

\begin{tabular}{lcccccccc}
\hline & \multicolumn{7}{c}{ Seedling nutritional traits } \\
\cline { 2 - 8 } Initial field height (Hc) & CPPA & CPR & CtPPA & CtPR & CtPT & EUP-PA & EUP-R & EUP-T \\
GD (\%) 12.5 & GD (\%) & GD (\%) & GD (\%) & GD (\%) & GD (\%) & GD (\%) & GD (\%) & GD (\%) \\
& 28.8 & 18.3 & 53.9 & 45.7 & 46.8 & 40.6 & 30.2 & 34.3 \\
\hline$r_{g}$ & -0.2 & -0.5 & 0.3 & 0.06 & 0.2 & 0.6 & 0.5 & 0.6 \\
GI (\%) & -3.4 & -6.5 & 4.3 & 0.8 & 3.1 & 8.1 & 7.14 & 8.8 \\
ESI (\%) & -27.2 & -51.9 & 34.7 & 6.4 & 24.8 & 64.9 & 57.1 & 70 \\
\hline
\end{tabular}

CPPA: P concentration in shoot; CPR: P concentration in root; CtPPA: P content in shoot; CtPR: P content in root; CtPT: total P content; EUP-PA: P use efficiency in shoot; EUP-R: P use efficiency in root; and EUP-T: total P use efficiency.

From that correlation, a genetic material may be obtained capable of simultaneously gathering several favorable attributes (CRUZ; REGAZZI, 2001). By the same token, where a trait is negatively correlated to another, one should be cautious that selection on one trait does not cause undesirable changes on other traits.

Table 3 above provides genotypic correlation coefficients among the traits of interest. From among nutritional traits, the lowest direct gain $(\mathrm{GD} \%=18.3)$ was estimated for CPR and the highest $(\mathrm{GD} \%=53.9)$ was estimated for CtPPA, considering a $25 \%$ selection. However, when observing estimates of expected indirect genetic gains $(\mathrm{GI} \%)$ in field height growth $(\mathrm{Hc})$, it is noted that the most efficient nutritional trait, at 120 days, was total P use efficiency (EUP-T), with a GI of $8.8 \%$, revealing an indirect selection efficiency (ESI) of 70.0\%. Other important nutritional traits, showing an ESI above $50 \%$, included EUP-PA and EUP-R, with $64.9 \%$ and $57.1 \%$ respectively. These ESI values thus suggest that the nutritional trait 'P use efficiency' can be an indicator of seedling quality in this clonal population.

According to Falconer (1987), indirect selection constitutes an important strategy for improving low heritability traits and/or traits considered difficult to measure.

These higher ESI values were due to the heritability of initial height growth in the field $(\mathrm{Hc})\left(\mathrm{h}^{2}=80 \%\right)$ being relatively lower than $\mathrm{P}$ use efficiency traits and/or due to the higher genotypic correlation values (Table 3 ). From Table 3 it is noted that the genotypic correlation coefficients $\left(\mathrm{r}_{\mathrm{g}}\right)$ found between Hc and EUP-T, Hc and EUP-R, and Hc and EUP-PA were $0.6,0.5$ and 0.6 respectively.

Cerne, Lavras, v. 17, n. 3, p. 303-308, jul./set. 2011
The negative values of genotypic correlation between Hc and CPPA, CPR and CPT were due to the fact that, in these concentration traits, there may be a dilution of $\mathrm{P}$ in the dry matter of seedlings

Table 4 provides mean values per clone type for all nutritional traits of interest. Considering only the traits showing better indirect gain responses in initial field height, it is noted that EUP-PA ranged between 10.830 $\mathrm{g}^{2} \cdot \mathrm{mg}^{-1}$ (clone ITA-011) and $31.030 \mathrm{~g}^{2} \cdot \mathrm{mg}^{-1}$ (clone ITA018); EUP-R ranged between $4.213 \mathrm{~g}^{2} \cdot \mathrm{mg}^{-1}$ (clone ITA011) and $10.797 \mathrm{~g}^{2} \cdot \mathrm{mg}^{-1}$ (clone ITA-063), while EUP-T ranged between $7.253 \mathrm{~g}^{2} \cdot \mathrm{mg}^{-1}$ (clone ITA-011) and 18.036 $\mathrm{g}^{2} \cdot \mathrm{mg}^{-1}$ (clone ITA 018).

Clones ITA-063 and ITA-069 showed the highest mean values of $\mathrm{Hc}$ (height of field seedlings), 2.8 and $2.7 \mathrm{~m}$ respectively. Considering only those traits with higher ESI values, it is noted that said clones are included among clones also showing the highest estimated means for EUP-T, EUP-PA and EUP-R.

In the case of forest stands, the shoot portion being economically more important, $\mathrm{P}$ use efficiency becomes a good indicator of nutrient conversion into biomass, in Eucalyptus clones (FURTINI NETO, 1994).

Results found in this study point to different behavioral patterns in eucalyptus clones regarding nutritional phosphorus use efficiency. As far as forest activity is concerned, given the wide assortment of species and genotypes used as well as the use of differing fertility soils, this aspect should be given special attention, so as to ensure that the interaction between soil $\mathrm{x}$ species and/ or genotypes is done sensibly. 
Table 4 - Mean estimates for nutritional traits regarding height of young field plants, at age eight months, of E. urophylla clones.

Tabela 4 - Estimativas de médias para características nutricionais de altura de plantas jovens no campo, aos oito meses de idade, de clones de E. urophylla.

\begin{tabular}{|c|c|c|c|c|c|c|c|c|c|}
\hline \multirow{2}{*}{ Clone } & $\mathrm{Hc}$ & CPPA & CPR & CtPPA & $\mathrm{CtPR}$ & $\mathrm{CtPT}$ & EUP-PA & EUP-R & EUP-T \\
\hline & $(\mathrm{m})$ & $\left(\mathrm{g} \cdot \mathrm{kg}^{-1}\right)$ & $\left(\mathrm{g} \cdot \mathrm{kg}^{-1}\right)$ & (mg.plant ${ }^{-1}$ ) & $\left(\right.$ mg.plant $\left.t^{-1}\right)$ & (mg.plant ${ }^{-1}$ ) & $\left(\mathrm{g}^{2} \cdot \mathrm{mg}^{-1}\right)$ & $\left(\mathrm{g}^{2} \cdot \mathrm{mg}^{-1}\right)$ & $\left(\mathrm{g}^{2} \cdot \mathrm{mg}^{-1}\right)$ \\
\hline ITA 011 & 2.3 & 50.67 & 57.72 & 0.028 & 0.141 & 0.086 & 10.83 & 4.213 & 7.253 \\
\hline ITA 018 & 2.5 & 36.52 & 52.68 & 0.041 & 0.251 & 0.143 & 31.03 & 9.037 & 18.036 \\
\hline ITA 022 & 2.1 & 50.71 & 63.51 & 0.039 & 0.270 & 0.138 & 15.60 & 6.683 & 10.606 \\
\hline ITA 062 & 2.7 & 45.36 & 53.89 & 0.035 & 0.172 & 0.108 & 17.01 & 6.043 & 11.053 \\
\hline ITA 063 & 2.8 & 60.16 & 57.51 & 0.077 & 0.354 & 0.223 & 21.25 & 10.797 & 16.143 \\
\hline ITA 068 & 2.0 & 44.93 & 51.08 & 0.034 & 0.199 & 0.111 & 16.98 & 7.610 & 12.003 \\
\hline ITA 069 & 2.7 & 28.29 & 35.15 & 0.023 & 0.110 & 0.071 & 28.21 & 9.057 & 17.596 \\
\hline ITA 090 & 2.6 & 35.46 & 45.92 & 0.031 & 0.201 & 0.107 & 24.80 & 9.583 & 16.183 \\
\hline
\end{tabular}

Hc: height of field seedlings, after eight months; CPPA: P concentration in shoot; CPR: P concentration in root; CtPPA: P content in shoot; CtPR: P content in root; CtPT: total P content; EUP-PA: P use efficiency in shoot; EUP-R: P use efficiency in root; and EUP-T: total P use efficiency.

\section{CONCLUSIONS}

Significant differences were found among clones regarding genotypes, for all traits of interest.

Heritability values were found to be relatively high.

A high correlation was found between initial field height and EUP-T, EUP-PA and EUP-R, for nutritional traits.

Clone ITA063 was found to have the highest CtP value, while clone ITA 069, the lowest.

The most P use efficient clone was ITA063, while the most inefficient (EUP-T, EUP-PA and EUP-R) was ITA 011.

\section{REFERENCES}

ASSOCIAÇÃO BRASILEIRA DE PRODUTORES DE FLORESTAS PLANTADAS. Anuário estatístico da

ABRAF: ano base 2008. Brasília, 2009. 129 p.

ASSOCIATION OF OFFICIAL ANALYTICAL CHEMISTS Official methods of analysis. 12. ed. Washington, 1975. $1094 \mathrm{p}$.

COMPANHIA DE PESQUISA DE RECURSOS MINERAIS. Projeto cadastro de abastecimento por águas subterrâneas, Estados de Minas Gerais e Bahia: diagnóstico do município de Taiobeiras, MG. Belo Horizonte, 2004. 15 p.
COTTERIL, P. P.; DEAN, C. A successful tree breeding with index selection. [S.1.]: CSIRO, 1990. 80 p.

CRUZ, C. D. Aplicativo computacional em genética e estatística: programa Genes, Versão Windows. Viçosa, MG: UFV, 2001. 648 p.

CRUZ, C. D.; CARNEIRO, P. C. S. Modelos biométricos aplicados ao melhoramento genético. Viçosa, MG: UFV, 2003.585 p.

CRUZ, C. D.; REGAZZI, A. J. Modelos biométricos aplicados ao melhoramento genético. 2. ed. Viçosa, MG: UFV, 2001. 390 p.

FALCONER, D. S. Introdução à genética quantitativa. Viçosa, MG: UFV, 1987. 279 p.

FURLANI, A. M. C.; BATAGLIA, O. C.; FURTINI, P. R.; AZZINI, L. E.; CAMARGO, O. A. B. Avaliação de genótipos de arroz quanto à eficiência na utilização de fósforo em solução nutritiva e em solo. Revista Brasileira de Ciência do Solo, Campinas, v. 7, n. 3, p. 291-302, set./dez. 1984.

FURTINI NETO, A. E. Eficiência nutricional, cinética de absorção e frações fosfatadas em Eucalyptus ssp. 1994. 99 p. Tese (Doutorado) - Universidade Federal de Viçosa, Viçosa, 1994.

Cerne, Lavras, v. 17, n. 3, p. 303-308, jul./set. 2011 
GOMES, J. M.; COUTO, L.; LEITE, H. G.; XAVIER, A.; GARCIA, S. L. R. Parâmetros morfológicos na avaliação de qualidade de mudas de Eucalyptus grandis. Revista Árvore, Viçosa, v. 26, n. 6, p. 655-664, nov./dez. 2002.

LUCA, E. F. Eficiência de uso do fosfato de cálcio por mudas de Eucalyptus grandis. 1997. Dissertação (Mestrado) - Escola Superior de Agricultura “Luiz de Queiroz”, Piracicaba, 1997.

MACHADO, C. T. T. Caracterização de genótipos de milho quanto a parâmetros morfológicos, fisiológicos e microbiológicos associados a eficiência e absorção e uso do fósforo. 2000. 366 p. Tese (Doutorado) - Universidade Federal Rural do Rio de Janeiro, Seropédica, 2000.

SIDDIQUI, M. Y.; GLASS, A. D. M. Utilization index; a modified approach to the estimation and comparison of nutrient utilization efficiency in plants. Journal Plant Nutrition, New York, v. 4, n. 3, p. 289-302, 1981.

SWIADER, J. M.; CHYAN, Y.; FREIJI, F. G. Genotypic differences in nitrate uptake and utilization efficiency in pumpkin hybrids. Journal of Plant Nutrition, v. 17, n. 10, p. 1687-1699, 1994.

TOMÉ, M. A. Blocos fixos ou aleatórios?: o caso dos ensaios em látice no melhoramento vegetal. Ciência $\mathbf{e}$ Agrotecnologia, Lavras, v. 26, n. 3, p. 576-584, maio/jun. 2002.

VENCOVSKY, R.; BARRIGA, P. Genética biométrica no fito melhoramento. Ribeirão Preto: Sociedade Brasileira de Genética, 1992. 406 p.

Cerne, Lavras, v. 17, n. 3, p. 303-308, jul./set. 2011 